Н. В. Срмілова ${ }^{1}$, С. Г. Кислиця ${ }^{1}$, Я. Р. Буркун ${ }^{1}$, А. Г. Гончаров ${ }^{2}$

${ }^{1}$ Національний університет «Полтавська політехніка імені Юрія Кондратюка», Полтава, Україна

${ }^{2}$ Полтавский автоагрегатний завод, Полтава, Україна

\title{
РОЗРОБЛЕННЯ СУЧАСНОЇ СИСТЕМИ АВТОМАТИЧНОГО КЕРУВАННЯ ЕЛЕКТРОПРИВОДОМ БЕТОНОРОЗДАВАЧА
}

\begin{abstract}
Анотація. Проаналізувавши особливості конструкції, принцип роботи та електропривод бетонороздавача типу СМЖ-69А, автори прийшли до висновку, що найбільш гостро потребує модернізації механізм переміщення цього пристрою та система його керування. Для підвищення ефективності роботи запропоновано застосувати частотнорегульований електропривод механізму переміщення на базі АД з короткозамкненим ротором. Рекомендовано замінити застарілий привод пересування у вигляді двигуна, редуктора і ланцюгової передачі на мотор-редуктор, що дозволить звільнити місце для встановлення контролерів та іншого обладнання системи автоматичного керування. Для механізму пересування бетонороздавача обрано сучасний мотор-редуктор, розроблена схема керування електроприводом на базі ПЛК. Пропонується застосувати тензометричний метод зважування бетонної суміші, для чого бункер з бетонною масою встановлюється на тензодатчиках. При заповненні бункера бетонороздавача до певної маси сигнал $з$ тензодатчиків надходить на контролер, після чого програма починає працювати. Вхідним сигналом $\epsilon$ маса бетонної суміші, що подається в бункер, а вихідним - напруга, яка подається на контролер, а потім, через перетворювач частоти, на об'єкт управління - привід пересування бетонороздавача. Керуючим впливом об'єкта керування (ОК) являється напруга, що подається на мотор-редуктор, а збурювальним впливом - сила статичного навантаження від ваги бетонороздавача, ваги бетонної суміші в бункері та сили опору розрівнюючого пристрою. Розроблена математична модель ОК, за допомогою якої проведені дослідження перехідних процесів об'єкту керування шляхом зміни керуючого та збурювального впливів. Аналіз перехідних процесів довів працездатність та якість системи керування. Розроблений алгоритм функціонування системи автоматичного керування бетонороздавачем, на базі якого побудована програма для ПЛК. Проведена технічна реалізація САК, обрані необхідні елементи та пристрої. Розрахована авторами економічна ефективність від проведеної модернізації довела ії доцільність.
\end{abstract}

Ключов і слов а : система керування, бетонороздавач, тензодатчик, математична модель, збурення.

\section{Постановка проблеми}

Механізація та автоматизація процесу укладання бетону в форму дозволяє значно підвищити продуктивність, спростити роботу людини, поліпшити якість виробів, що випускаються. Наш час характеризується широким здійсненням автоматизації виробництва на базі використання програмованих логічних контролерів. Цей прогрес торкнувся й промисловості будівельних матеріалів, зокрема бетонороздавачів і виробництва бетонних виробів.

Приріст виробництва бетонних виробів повинен відбуватися за рахунок ефективнішого використання виробничих потужностей залізобетонного виробництва (ЗБВ), а поліпшення якості продукції за рахунок вдосконалення технології. Для реалізації цієї мети необхідно оснастити заводи ЗБВ сучасним високопродуктивним технологічним обладнанням.

Оснащення заводів ЗБВ проводиться за рахунок придбання нового високопродуктивного технологічного обладнання та за допомогою модернізації застарілого. Модернізація механічного обладнання 3 подальшою автоматизацією перетворює застаріле обладнання на сучасне з більш низькою вартістю у порівнянні з новим.

Модернізація проводиться таким чином: встановлюють приводи 3 меншою енергоємністю але 3 більшими крутними моментами, тобто замінюють застарілий привод на сучасний $з$ відповідною системою автоматизації. Зміна застарілих приводів дозволяє звільнити місце для встановлення контролерів, датчиків, перетворювачів частоти, тим самим вдосконалити систему.
Аналіз останніх досліджень і публікацій. В дослідженні використана низка джерел, в яких розглянуті основні питання укладання бетону та застосування новітнього електротехнічного обладнання. В роботах [1-3] розкриті питання виготовлення та впровадження в обіг нових видів бетороздавачів, приведені характеристики серійного підйомнотранспортного обладнання. Особлива увага приділяється обладнанню, розробленому в останні роки. В джерелах дані рекомендації по вибору обладнання для механізації трудомістких завантажувальнорозвантажувальних та транспортних робіт. В роботах [4-7] досліджені можливості автоматизації технологічного процесу укладання бетону, як одному 3 важливих для розвитку сучасної будівельної промисловості. При цьому особлива увага приділяється засобам автоматизації для реальних технологічних розчинів та режимів роботи обладнання в процесі виробництва. Наведені сучасні системи керування, в тому числі, з використанням обчислювальної техніки. У підручниках [8-9] розкриваються питання електропривода та автоматизації робочих режимів типових промислових механізмів неперервної та циклічної дії. Загальні положення доповнюються аналізом окремих схем електропривода механізмів різних машин, установок та технологічних комплексів. Викладено особливості електромеханічних систем автоматизації та їх найважливішого виду - електромеханічних систем автоматичного керування; обгрунтовано необхідність застосування системного підходу під час вивчення цих систем з врахуванням особливостей технологічних об'єктів керування, властивостей різних видів електроприводів. Розглянуто 
взаємовплив технологічних об'єктів та електроприводів у системі автоматичного керування; класичні та сучасні керовані електроприводи із застосуванням новітніх методів керування; загальні технікоекономічні та експлуатаційні питання: енергозбереження, застосування екстремальних енергозберігаючих систем, захисту, діагностики та моніторингу.

При аналізі літературних джерел по темі можна зробити висновок, що питання процесу укладання бетону недостатньо досліджені, контроль кількості бетону або відсутній, або недостатній. Практично відсутні дані про використання частотно-регульованого електроприводу в технології укладання бетону. Мало інформації про залежність надійності укладання бетону від якості керування переміщенням бетонороздавача.

Мета статті - аналіз, модернізація та автоматизація ділянки укладання бетону в форми та підвищення продуктивності роботи за рахунок модернізації бетонороздавача типу СМЖ-69А, а саме електропривода механізму його переміщення.

\section{Основна частина}

Бетонороздавач - це пристрій, що видає бетонну суміш у форму та розрівнює іiі при формуванні багатопустотних панелей перекриттів житлових будівель та інших одношарових залізобетонних виробів. Рама бетонороздавача представляє собою зварну конструкцію портального типу. Нижня частина їі складається 3 чотирьох поздовжніх швелерів, попарно зв'язаних між собою, що несуть два приводних та два ходових колеса. Верхня частина рами складається 3 поздовжніх і поперечних балок. На верхню обв'язку рами встановлений бункер та бак для води. У верхній частині змонтовані привод пересування, привод живильника та механізм підйому заслінки.

Привод пересування складається з двошвидкісного електродвигуна, редуктора, гальма та двох ланцюгових передач. Привод живильника скомпоно- ваний $з$ електродвигуна, редуктора, зубчастої пари та ланцюгової передачі. Розрівнюючий пристрій встановлюється під живильником, він являє собою шарнірно-змонтовану на боковинах приводну поворотну лійку. Положення розрівнюючого пристрою регулюється в залежності від товщини формованих виробів. Заслінка бункера відкривається та закривається за допомогою пневмоциліндра, що підвішений до бункера.

Проаналізувавши конструкцію та принцип роботи бетонороздавача, автори прийшли до висновку, що найбільш гостро потребує модернізації механізм переміщення цього пристрою.

Механізм переміщення бетонороздавача має нерегульований електропривод, що приводить до значної перевитрати електроенергії, тому потребує плавного регулювання швидкості. Діапазон регулювання за швидкістю змінюється в широких межах та, залежно від завантаженості бетонороздавача, механізм рухається з різною швидкістю. Суттєво зменшити енергозатрати можливо при застосуванні частотно-регульованого електропривода на базі АД з короткозамкненим ротором. При використанні частотно-регульованого електропривода 3'являються наступні технічні можливості: обмеження струму на рівні номінального в пускових, робочих та аварійних режимах; плавний розгін та гальмування бетонороздавача; регулювання швидкості від мінімальної до номінальної та вище номінальної. Крім того, монтаж частотно-регульованого електропривода не потребує значних додаткових витрат.

Враховуючи вищеописане, було вирішено для реалізації енергозберігаючого режиму роботи механізму переміщення бетонороздавача обрати керований електропривод за схемою ПЧ-АД, який дозволить використовувати найоптимальніший режим роботи цього механізму.

Даний режим реалізується стандартною структурною схемою (рис.1).

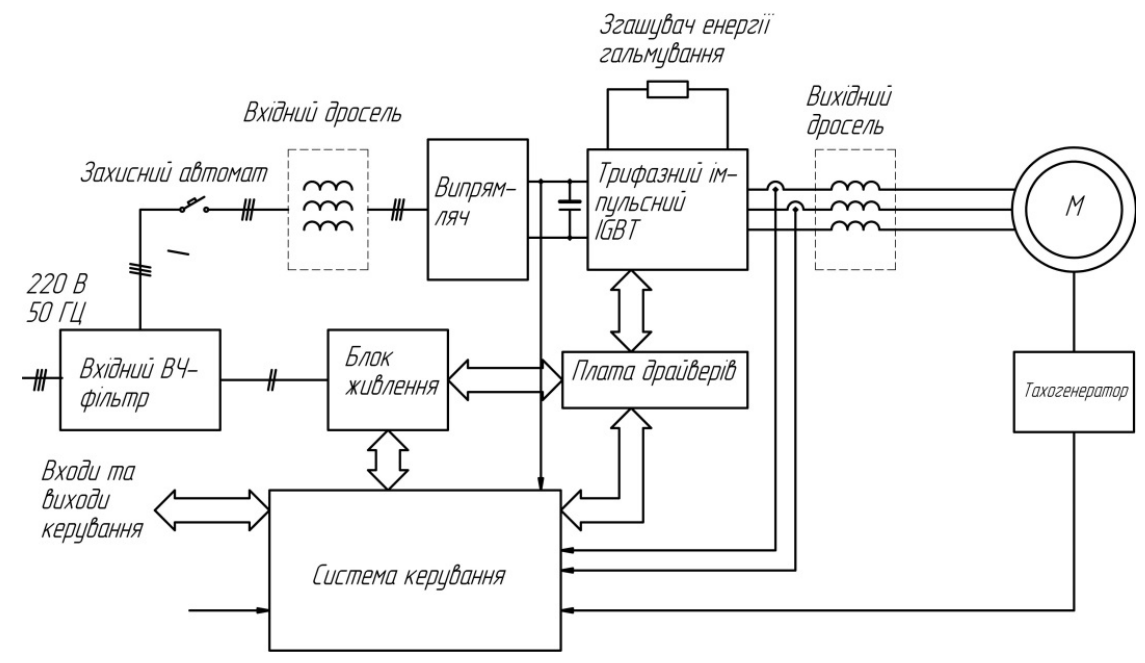

Рис. 1. Структурна схема ПЧ-АД

При модернізації бетонороздавача запропоновано провести заміну застарілого привода пересування у вигляді двигуна, редуктора і ланцюгової передачі на мотор-редуктор 1, що дозволить звільнити місце для установки контролерів, датчиків, перетворювачів частоти i, тим самим, автоматизувати систему (рис. 2). 


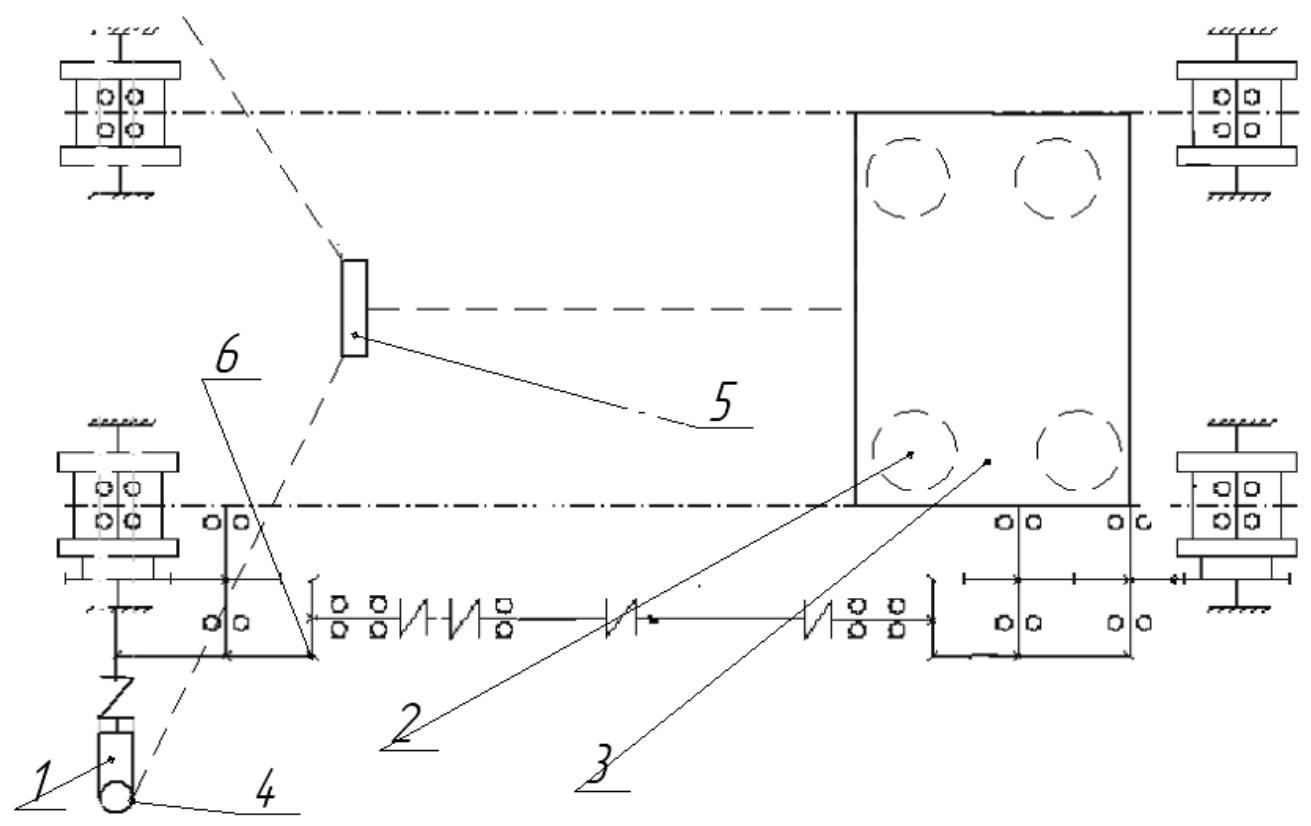

Рис. 2. Запропонована кінематична схема приводу пересування бетонороздавача (1 - мотор-редуктор; 2 - тензодатчики; 3 - платформа; 4 - перетворювач частоти; 5 - контролер; 6 - вал)

Бункер розміщується на сталевий платформі 3, яка буде розташована на тензодатчиках 2, що з'єднуються в ланцюг. При заповненні бункера бетонороздавача до певної маси сигнал 3 тензодатчиків надходить на програмоване реле та контролер, після чого система починає працювати. Вхідним сигналом тут $€$ маса бетонної суміші, що подається в бункер, а вихідним - напруга, яка подається на контролер, а потім, через перетворювач частоти, на об'єкт керування (ОК). Так як об'єктом керування $є$ привід пересування бетонороздавача, то вихідним параметром буде його лінійна швидкість.

Керуючим впливом ОК являється напруга, що подається на мотор-редуктор, а збурювальним впливом - сила статичного навантаження від ваги бетонороздавача, ваги бетонної суміші в бункері та сили опору розрівнюючого пристрою. Основним обмеженням, що накладається на вихідну координату, є швидкість надходження бетонної суміші зі стрічкового живильника і швидкість розподілу бетонної суміші у формі.

Проведений розрахунок $[10,11]$ показав, що загальна потужність, необхідна для пересування бетонороздавача, складає $\mathrm{N}_{\Sigma}=2,2$ кВт. У зв'язку з тим, що мотороредукторів у нас буде два, потужність кожного повинна бути не менше, ніж $\mathrm{N}=1,1$ кВт. Тому для реалізації було обрано двоступеневий циліндричний мотор-редуктор типу 3МП-40 3 двигуном АИР 80В5 потужністю $\mathrm{N}_{д}=1,5$ кВт, 3 номінальним крутним моментом на вихідному валу рівним $\mathrm{M}_{\mathrm{H}}=375 \mathrm{H} \cdot \mathrm{M}$.

Важливим елементом для контролю маси бетонної суміші $\epsilon$ електронно-тензометричні ваги, що складаються 3 наступних основних елементів: тензодатчиків (первинних приладів, що показують) та вторинних приладів, а також лінії зв'язку. При тензометричному методі зважування використовується явище тензоефекту - зміна електричного опору дротяної решітки, наклеєною на пружний елемент, при iї деформації під навантаженням. Дія електронних тензометричних ваг заснована на існуванні лінійної залежності між деформацією вантажоприймального вимірювального елемента та зміною його опору.

На зварних тумбах, які знаходяться на рамі бетонороздавача під бункером, будуть розташовані тензодатчики, на яких розмістимо платформу для розташування на ній бункера. Використовуємо тензодатчики в комплекті зі спеціальним модулем вводу сигналу тензодатчиків Seneca Z-SG.

Після попереднього обрахунку параметрів двигуна та інших елементів системи була розроблена структурна схема математичної моделі асинхронного двигуна $з$ тензодатчиком (рис. 3).

Для проведення досліджень системи на підставі структурної схеми в програмному середовищі Matlab розроблена обчислювальна модель ОК (рис. 4).

За допомогою моделі були проведені дослідження перехідних процесів об'єкту керування шляхом зміни керуючого та збурювального впливів.

При дослідженні керуючого впливу вхідним сигналом на ОК була напруга, що подається на статорну обмотку АД (рис. 5).

Дослідження проводилися для трьох значень частоти 104, 157, 314 рад/с в «малому» та в «великому». При дослідженні в «малому» частота приймалася як $10 \%$ від сталого значення в «великому». Стрибок показує збільшення швидкості за рахунок збільшення частоти.

При дослідженні ОК за допомогою зміни збурювального впливу вхідним сигналом ми залишили напруги таких же частот як і в попередньому випадку, а збурювальним впливом тут була зміна маси.

У нашому випадку це буде збільшення маси (вага бетонороздавача 3 бетонною сумішшю). За рахунок збільшення маси збільшиться сила статичного навантаження та, відповідно, сила тертя. Швидкість бетонороздавача буде падати (рис. 6). 


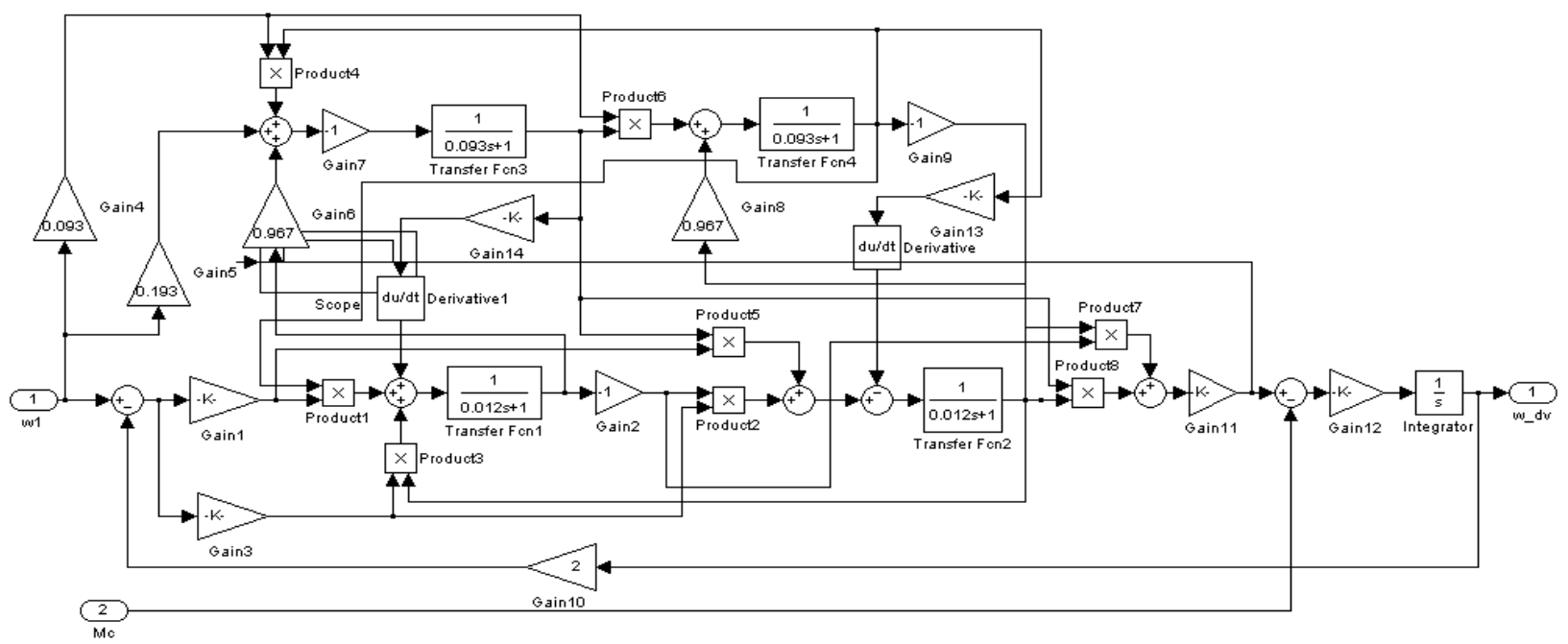

Рис. 3. Структурна схема математичної моделі асинхронного двигуна з тензодатчиком

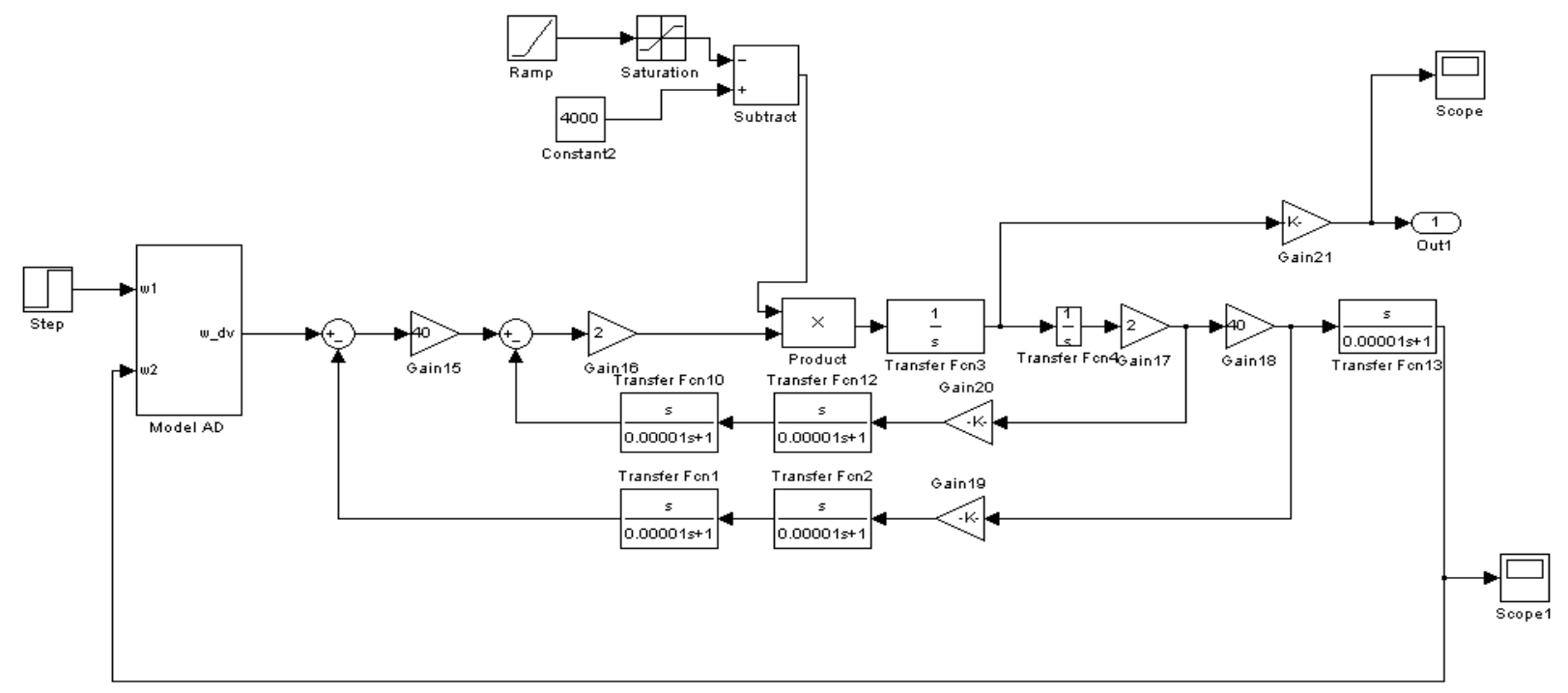

Рис. 4. Обчислювальна модель ОК в программному середовищі Matlab

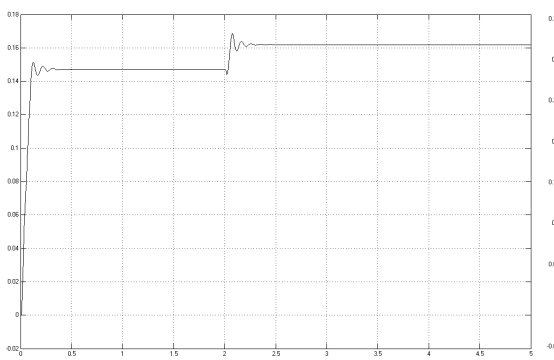

$\mathrm{a}-\omega=104$ рад/c

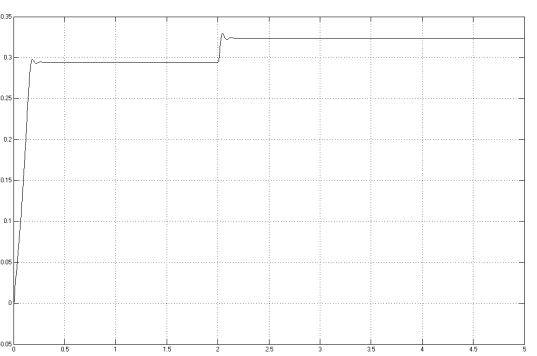

$\sigma-\omega=157 \mathrm{paд} / \mathrm{c}$

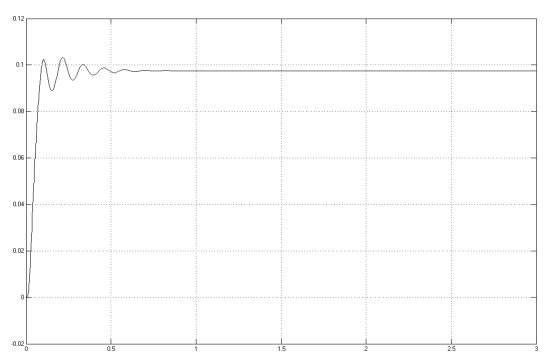

в $-\omega=314$ рад/с

Рис. 5. Дослідження ОК при зміні керуючого впливу

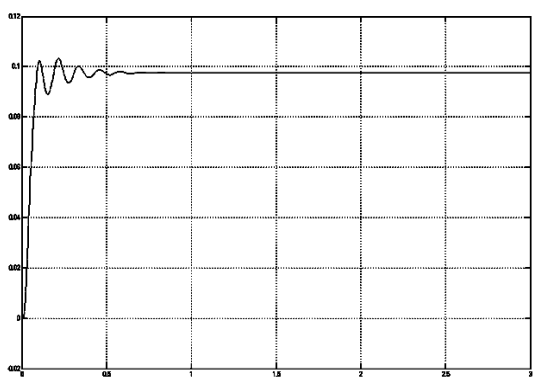

$\mathrm{a}-\omega=104$ рад/c

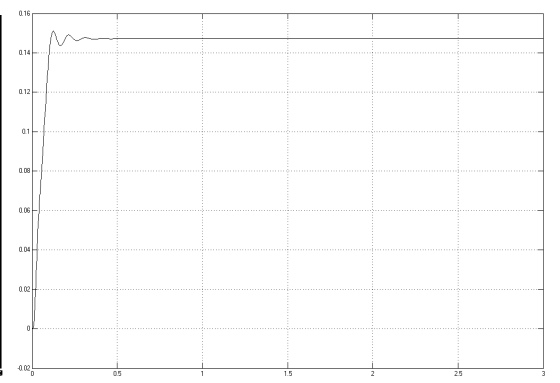

$\sigma-\omega=157 \mathrm{paд} / \mathrm{c}$

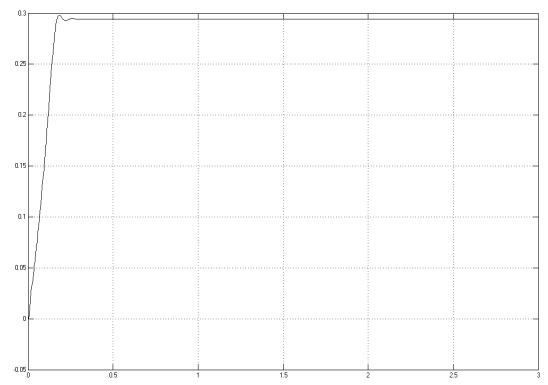

в $-\omega=314$ рад/с

Рис. 6. Дослідження ОК при зміні збурювального впливу 
Аналіз перехідних процесів показує, що систе-

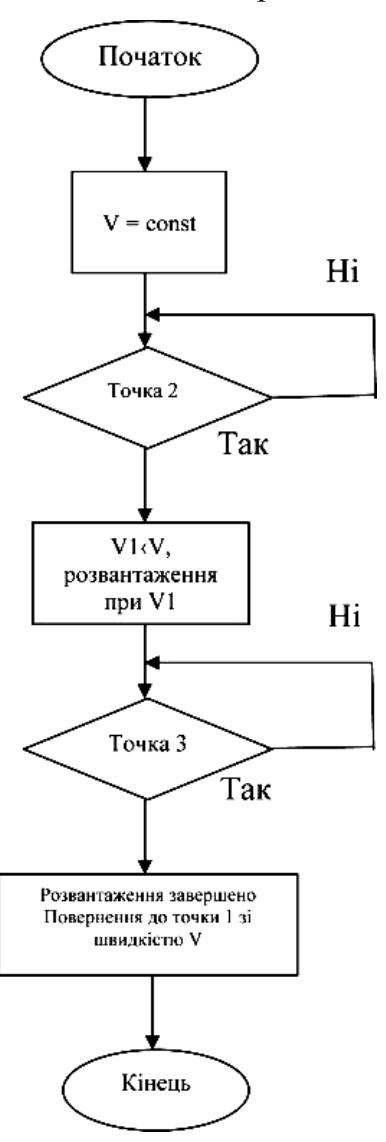

Рис. 7. Алгоритм функціонування САК

ма на всіх частотах має незначне перерегулювання, малу коливальність, достатньо високу швидкодію та задовольняє вимогам пересування бетонороздавача.

Розроблений алгоритм функціонування системи автоматичного керування бетонороздавачем (рис. 7).

При надходженні сигналу 3 тензодатчиків і замиканні кінцевого вимикача бетонороздавач починає рух $з$ постійною швидкістю V до точки 2 (початок вивантаження бетону в форму) в якій відбувається перемикання кінцевого вимикача та швидкість V знижується до швидкості V1, при досягненні точки 3 замикається кінцевий вимикач, розмикається шляховий вимикач, включається реверс та бетонороздавач 3 постійною первісною швидкістю V повертається до початкової точки 1. На базі цього алгоритму розроблено програму для контролера.

\section{Технічна реалізація розробленої САК}

На верхню раму бетонороздавача встановлюються чотири тензодатчики типу ВАМ350-2ЕВ, які з'єднуються в коло. Поверх датчиків встановлюється сталева платформа, на якій розміщується бункер. Датчики підключаються по мостовій схемі через модуль Z-SG (рис. 8).

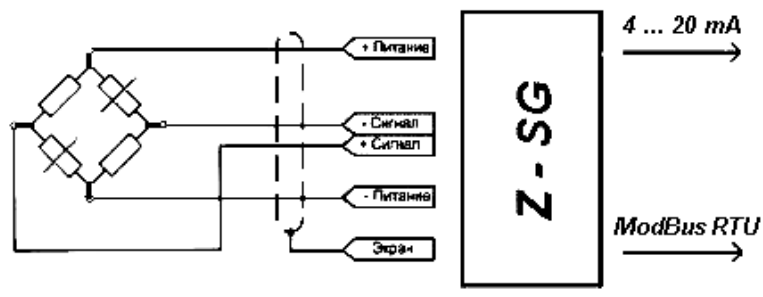

Рис. 8. Схема підключення вагового модуля

Модуль введення сигналів тензодатчиків Seneca Z-SG - це пристрій, що перетворює сигнал від тензодатчика в уніфікований сигнал по струму або напрузі. Додатково передача даних здійснюється по цифровому каналу ModBus RTU, що дозволяє з високою швидкістю (до 115200 біт/с) та на достатньо великі відстані передавати дані тензометричного датчика до програмуючих контролерів. Наявність такого каналу дозволяє здійснювати своєчасний запуск та зупинку виконавчих механізмів в ваговимірювальних дозуючих системах. Похибка перетво- рювача Seneca Z-SG не перевищує 0,01\%. Наявність зовнішніх LED індикаторів (живлення, збій/помилка, передача даних, прийом даних) на модулі введення полегшує контроль стану системи.

3 перетворювача сигналів тензодатчиків електричний сигнал йде на програмований логічний контролер (ПЛК) серії Master. Такі спеціалізовані контролери компанії Інсат СПб застосовуються для безперервного та дискретного вагового дозування сипучих та рідких компонентів. Вузька спеціалізація цих контролерів, вбудовані алгоритми високоточного дозування дозволили досягти дуже гарного співвідношення ціна/функціональність. Дозуючі та вагові контролери Master застосовуються для автоматизації систем дозування: одного- та багатокомпонентного вагового безперервного дозування; вагового введення рідких компонентів як дискретного, так і безперервного.

Сигнал 3 контролера надходить на перетворювач частоти SEW-EURODRIVE MOVIMOT, що вбудований в спеціальний клемник двигуна, з якого сигнал певної частоти надходить на двигун, виконуючи процес регулювання. MOVIMOT - це базовий компонент для децентралізованих приводних систем, а також гарна заміна механічного варіатора або двохшвидкісного двигуна.

Відмінні особливості цієї серії: номінальна потужність двигуна від 0,37 до 3 кВт, живлення 3фазна мережа $380 \mathrm{~B}$, діапазон регулювання 1:5 або $1: 10$ з постійним моментом в режимі S1 100\%, оптимальне керування двигуном 3 гальмом - не потрібні додаткові контактори та гальмівні випрямлячі.

В якості цифрового перетворювача обрано цифровий електронний підсилювач фірми НВМ (Нiмеччина) $\mathrm{AD} 105$, що має 2-х провідний напівдуплексний послідовний інтерфейс RS-485, здійснює цифрову фільтрацію і масштабування вимірювального сигналу.

Режим роботи двигуна задається початковим налаштуваннями частотного перетворювача та збурювальною дією тензодатчиків, які вмикаються через аналогово-цифрові перетворювачі, що перетворюють аналоговий сигнал в сигнал цифрових кодів, котрі поступають на порт вводу мікроконтроллера та вбудованого алгоритму переміщення. При зміні ваги бетонної суміші тензометричні ваги передають сигнал на уповільнення чи збільшення швидкості двигуна, виконуючи тим самим процес регулювання. Це й дає підвищення продуктивності роботи всього бетонороздавача.

Доведена економічна ефективність від проведеної модернізації, очікуваний економічний ефект складає близько 17500 грн, а термін окупності близько 2 років [10].

\section{Висновки}

1. Проведений аналіз показує, що питання процесу укладання бетону недостатньо досліджені, контроль кількості бетону або відсутній, або недостатній. Практично відсутні дані про використання частотно-регульованого електроприводу в технології укладання бетону. Проаналізувавши конструкцію та принцип роботи бетонороздавача, автори прийшли 
до висновку, що найбільш гостро потребує модернізації механізм переміщення цього пристрою.

2. Запропоновано підвищити енергетичну ефективність пристрою шляхом зменшення енергозатрат при застосуванні частотно-регульованого електропривода механізму переміщення на базі АД з короткозамкненим ротором.

3. В роботі по модернізації бетонороздавача проведена заміна застарілого привода пересування у вигляді двигуна, редуктора і ланцюгової передачі на мотор-редуктор, що дозволяє звільнити місце для установки контролерів, датчиків, перетворювачів частоти i, тим самим, автоматизувати систему. Розрахована потужність приводу пересування бетонороздавача, обрано мотор-редуктор, розроблена схема керування електроприводом на базі ПЛК.
4. Розроблена математична модель ОК, за допомогою якої проведені дослідження перехідних процесів об'єкту керування шляхом зміни керуючого та збурювального впливів. Аналіз перехідних процесів показує, що розроблена система на всіх частотах має незначне перерегулювання, малу коливальність, достатньо високу швидкодію та задовольняє вимогам пересування бетонороздавача.

5. Розроблений алгоритм функціонування системи автоматичного керування бетонороздавачем, на базі якого побудована програма для ПЛК.

6. Проведена технічна реалізація САК, обрані необхідні елементи та пристрої.

7. Розрахована авторами економічна ефективність від проведеної модернізації довела іiі доцільність.

\section{СПИСОК ЛІТЕРАТУРИ}

1. Якименко О. В. Технологія будівельного виробництва : навч. посібник / О. В. Якименко; Харків. нац. ун-т. міськ. госп-ва ім. О. М. Бекетова. - Харків: ХНУМГ, 2016. - 411 с.

2. Іщук О. О. Конспект лекцій з дисципліни «Організація технологічних процесів на підприємствах будівельної індустрії» / О. О. Іщук, О. В. Безусяк. - Рівне : НУВГП, 2010. - 182 с.

3. Кравцов А. И. Проектирование предприятий по производству бетонных и железобетонных конструкций: учебное пособие / А. И. Кравцов - Оренбург : ГОУ ОГУ, 2016. - 196 с.

4. Ельперін І.В. Автоматизація виробничих процесів: Підручник / І.В.Ельперін, О.М.Пупена, В.М.Сідлецький - К.: Ліра K, 2017. $-378 \mathrm{c}$

5. Кондращенко О. В. Матеріалознавство : навч. посібник / О. В. Кондращенко ; Харків. нац. акад. міськ. госп-ва. Харків : ХНАМГ, 2007. - $182 \mathrm{c}$.

6. Колбасин А.М., Либенко А.В. Принципы связного дозирования многокомпонентных смесей //А.М.Колбасин, А.В. Либенко. Новые технологии в автоматизации управления. Сб. науч. тр. МАДИ. - М. 2006, С. 73-75.

7. Колбасин А.М. Комбинированная система управления дозатора непрерывного действия //А.М. Колбасин, А.В.Илюхин, В.И.Марсов, Динь Ан Нинь. «Вестник МАДИ».- М. 2014, С. 69-72.

8. Попович М.Г. Електромеханичні системи автоматичного керування та електроприводи: навч.посібник / М.Г.Поповіч, О.Ю.Лозинський, В.Б.Клепиков та ін.; за ред. М.Г.Поповіча. - К.: Либідь. $-2005 .-680$ с.

9. Макаров А.М. Системы управления автоматизированным электроприводом переменного тока : учеб. пособие / А. М. Макаров, А. С. Сергеев, Е. Г. Крылов, Ю. П. Сердобинцев - Волгоград : ВолгГТУ, 2016. - 192 с.

10. Shefer O. Optimization of electric energy use in telecommunication objects under the conditions of non-linear loading / O. Shefer, B. Topikha, V. Shefer, O. Zhurkin // Systems of control, navigation and communication. - Poltava: PoltNTU, 2019. - no. 2 (54). - pp. 51-54.

11. Буркун Я. Р. Удосконалення САК електроприводом бетонороздавача: автореферат магістерської роботи / Я.Р. Буркун. - Полтава, ПолтНТУ, 2019. - 8 с.

Received (Надійшла) 17.12.2019

Accepted for publication (Прийнята до друку) 12.02.2020

\section{Development of a modern system for automatic control of a concrete distributor electric drive}

N. Yermilova, S. Kyslytsia, Y. Burkun, A. Goncharov

Abstract. Analyzing the features of the design, principle of operation and electric drive of the concrete mixer type SMZH-69A, the authors came to the conclusion that the mechanism of movement of this device and its control system most urgently needed modernization. In order to increase the efficiency of work, it is proposed to use a frequency-controlled electric drive of the mechanism of movement on the basis of an asynchronous motor with a short-circuited rotor. It is recommended to replace the outdated displacement actuator in the form of an engine, gearbox and chain drive on the motor-gearbox, which will allow space for the installation of controllers and other automatic control system equipment. A modern motor-gearbox has been selected for the mechanism of movement of the concrete spreader, a PLC-based electric drive control scheme has been developed. It is proposed to use a tensometric method of weighing the concrete mixture, for which a hopper with a concrete mass is mounted on the strain gauges. When filling the hopper of the concrete spreader to a certain mass, the signal from the load cells is sent to the controller, after which the program starts to work. The input signal is the mass of the concrete mixture fed into the hopper, and the output signal is the voltage applied to the controller and then, via the frequency converter, to the control object the drive of the concrete dispenser. The controlling influence of the control object $(\mathrm{CO})$ is the voltage applied to the gear reducer, and the disturbing influence is the static loading force from the weight of the concrete spreader, the weight of the concrete mixture in the hopper and the resistance force of the damper. An CO computational model was developed to investigate the transients of a control object by changing its control and disturbance influences. Analysis of transients has proven the efficiency and quality of the control system. The algorithm of functioning of the automatic control system of the concrete dispenser is developed, on the basis of which the program for the PLC, is developed. The technical implementation of the ACS was carried out, the necessary elements and devices were selected. The economic efficiency of the modernization carried out by the authors proved its expediency.

Keywords : control system, concrete dispenser, load cell, mathematical model, disturbance. 